\title{
(2347) Proposal to conserve the name Crataegus laciniata (Rosaceae) with a conserved type
}

\author{
Joel Calvo, ${ }^{1}$ Roman Ufimov ${ }^{2} \&$ Carlos Aedo ${ }^{1}$ \\ 1 Real Jardín Botánico-CSIC, Plaza Murillo 2, 28014 Madrid, Spain \\ 2 Komarov Botanical Institute of the Russian Academy of Sciences, 2 Prof. Popov St., 197376 Saint Petersburg, Russia \\ Author for correspondence: Joel Calvo, calvocasas@gmail.com \\ DOI http://dx.doi.org/10.12705/641.13
}

(2347) Crataegus laciniata Ucria, Nuova Racc. Opusc. Aut. Sicil. 6: 251. 1793 [Angiosp.: Ros.], nom. cons. prop.

Typus: Italy, Sicilia, Madonie Mts., Portella Colla, 3752'05" N $14^{\circ} 00^{\prime} 22^{\prime \prime}$ E, 1430 m, 14 Oct 2014, Domina \& al. (MA No. 884213; isotypi: BM, C, G, LE, MO, PAL), typ. cons. prop.

The name Crataegus laciniata Ucria is generally applied to a species characterized by displaying \pm lanate twigs, leaves, inflorescences, hypanthia, and fruits. The subterminal leaves of flowering shoots are deeply and narrowly lobed and they bear short petioles (0.1-0.3 the length of the lamina). The fruits are brick-red, $8-14 \mathrm{~mm}$ in diameter, and they have (1)2-3(5) pyrenes. It is distributed through the western Mediterranean, i.e., northern Algeria, Morocco, Sicily, and southeastern Spain.

The lectotype of C. laciniata designated by Christensen (in Syst. Bot. Monogr. 35: 112. 1992) does not match the traditional and current concept of this species and does not support the above usage of the name. His lectotypification leads the name $C$. laciniata to apply to C. monogyna var. lasiocarpa (Lange) K.I. Chr. (三 C. lasiocarpa Lange, Diagn. Pl. Iber. 2: 11. 1881). This taxon displays villous twigs, leaves, inflorescences, hypanthia, and fruits, and besides, the fruits are 5-9 $\mathrm{mm}$ in diameter and they have only 1 pyrene, exceptionally 2 . The type specimen (C barcode 10017870!) consists of a fruiting branch that undoubtedly corresponds to the C. monogyna group and it is from Sicily. The label shows "Crataegus sp. laciniata / Bernardino ab Ucria / Dedit Gussoni / Madonie". This information does not establish that the specimen was studied by Ucria. Taking into account that Ucria (1739-1796) died when Gussone (1787-1866) was nine years old, it does not seem feasible that they communicated with one another. Secondly, the presumed identification of the specimen by Gussone does not match the criteria that were elucidated in his own treatment (Fl. Sicul. Prodr. 1: 565-566. 1827). He characterized C. laciniata (under Mespilus laciniata (Ucria) Guss.) as a species displaying big fruits having $1-5$ pistils. He added in the discussion "aliquando simul cohaerent, hinc nihil mirum si pro unico descripserit Ucria" [sometimes the pistils stick together; hence, it is no wonder that Ucria described the species as monogynous]. Moreover, he included as a synonym the name Mespilus pubescens C. Presl (1822, non Pohl 1814), an illegitimate replaced synonym of $C$. pubescens $\mathrm{C}$. Presl (F1. Sicul. 1: XXIV. 1826), which is widely accepted as a heterotypic synonym of $C$. laciniata (Bertoloni, Fl. Ital. 5: 149. 1842-1844, sub Mespilus; Nyman, Consp. Fl. Eur.: 243. 1879; Lojacono-Pojero, Fl. Sicul. 1(2): 205. 1891, sub Mespilus; Muñoz Garmendia \& al. in Castroviejo, Fl. Iberica 6: 407. 1998; Greuter in Greuter \& Raab-Straube, Euro+Med Plantbase, http://www.emplantbase.org, accessed Aug 2014, sub Mespilus). On this basis, it is not certain that Christensen's designated lectotype is original material for Ucria's name. Moreover, Christensen's morphological interpretation differs from the species concept of $C$. laciniata established by most botanists. Although the protologue reads "floribus monogynis", which really characterizes C. monogyna Jacq. and its segregates, $C$. laciniata exceptionally displays only one pyrene as was already mentioned.

Alternatively, Christensen treated the taxon from the western Mediterranean with 2-3 pyrenes (here in the sense of $C$. laciniata) as C. orientalis subsp. presliana K.I. Chr. (三C. pubescens). However, we do not consider it appropriate to treat this taxon at infraspecific rank because the diagnostic characters are consistent and its distribution area is well delimited. On this basis, we and most earlier and modern botanists are inclined to regard it as a species distinct from C. orientalis Pall. ex M. Bieb. 
Therefore, since this species has consistently been accepted as C. laciniata, a name widely used in the taxonomic literature from its publication in 1793, e.g., by Candolle (Prodr. 2: 629. 1825), Bertoloni (1.c.), Willkomm (Suppl. Prodr. Fl. Hispan.: 221. 1893), Nyman (1.c.), Arcangeli (Comp. Fl. Ital.: 230. 1882), Lojacono-Pojero (1.c.), Jahandiez \& Maire (Cat. Pl. Maroc 2: 335. 1932), Lindberg (Itin. Medit.: 73. 1932), Sennen (Campagn. Bot.: 73. 1936), Amaral Franco (in Tutin \& al., Fl. Eur. 2: 77. 1968), Maire (Fl. Afrique N. 15: 138. 1980), Pignatti (Fl. Ital. 1: 613. 1982), Muñoz Garmendia \& al. (1.c.), Achhal (in Valdés \& al., Cat. Pl. Vasc. N. Maroc 1: 294. 2002), Cueto \& Giménez (in Blanca \& al., Fl. Andalucía Oriental 3: 34. 2009) and Greuter (1.c.), it is appropriate to conserve the name C. laciniata with a conserved type to preserve this usage.

According to Stafleu \& Cowan (in Regnum Veg. 115: 562. 1986) the location of Ucria's collection is unknown. However, there is a small herbarium kept at "Società Siciliana per la Storia Patria di Palermo", but we did not find any relevant specimen there. Our efforts to locate original material at PAL, NAP, and G were also unsuccessful. The lack of original material that will allow current usage of C. laciniata to be maintained leads us to propose a new specimen as type of the name, removing any uncertainty surrounding the application of this name. In agreement with the protologue, we select as the proposed conserved type of $C$. laciniata a Domina collection from Portella Colla (Madonie Mts.) in Sicily. The type is kept at MA, and there are isotypes at $\mathrm{BM}, \mathrm{C}, \mathrm{G}, \mathrm{LE}, \mathrm{MO}$, and PAL. The collection is in fruit and it can be readily studied that the fruits have 2-3 pyrenes.

If the proposal is rejected, the name $C$. laciniata must be applied at specific rank to C. lasiocarpa Lange, a name treated as a heterotypic synonym of C. monogyna Jacq. (F1. Austriac. 3: 50. 1775) by Christensen (1.c.: 111, sub C. monogyna var. lasiocarpa), Muñoz Garmendia \& al. (1.c.), and Greuter (1.c.). In addition, the name $C$. pubescens $C$. Presl would replace the widespread usage of $C$. laciniata. The name $C$. pubescens has been scarcely used and always included in the synonymy of $C$. laciniata. In order to preserve nomenclatural stability in accordance with Art. 14.1 and 14.2 of the Melbourne Code (McNeill \& al in Regnum Veg. 154. 2012), conservation of the name $C$. laciniata is here proposed.

\section{Acknowledgements}

We are grateful to Ib Friis (C) for providing high-quality images of Crataegus collections. Special thanks to Gianniantonio Domina (PAL) for kindly collecting the proposed type material, as well as to Félix Muñoz Garmendia (MA) for useful comments. This work was financed by Flora Iberica project (CGL2011-28613-C03-01). 